\title{
GROWING GENLISEA
}

RITA CORINO •Alessandria • Italy • rita.corino1972@gmail.com

\section{Introduction}

The Genlisea genus belongs to the Lentibulariaceae family and includes thirty carnivorous species originating in the tropical regions of Africa and Central and South America where they share the habitat with Drosera, Utricularia, Heliamphora, and Brocchinia. They occupy wet meadows that are poor in nutrients or sandy areas on the Venezuelan tepuis.

The Genlisea species do not have a real root system, but the carnivorous traps are modified underground leaves that anchor the plant to the ground and absorb liquids and nutrients. The trapleaves have lost pigmentation and also the ability to photosynthesize. Carnivory was demonstrated only in 1998, although the genus has been recognized since the beginning of the 1800s.

The above-ground basal leaves are arranged in a rosette and are of two types: spatulate or linear (Fig. 1), ranging in size from a few millimeters (G. pygmaea) to 12 centimeters (G. guianensis).

The trap

The leaf trap is certainly what distinguishes Genlisea and fascinates the growers. Starting from the surface of the soil, and roughly from the center of the rosette, a terete footstalk and then a hollow tube containing the vesicle develops downwards; the vesicle is a bulge, where the real digestion of the prey that have travelled up inside the trap itself takes place (Fig. 2; Front Cover). At the end
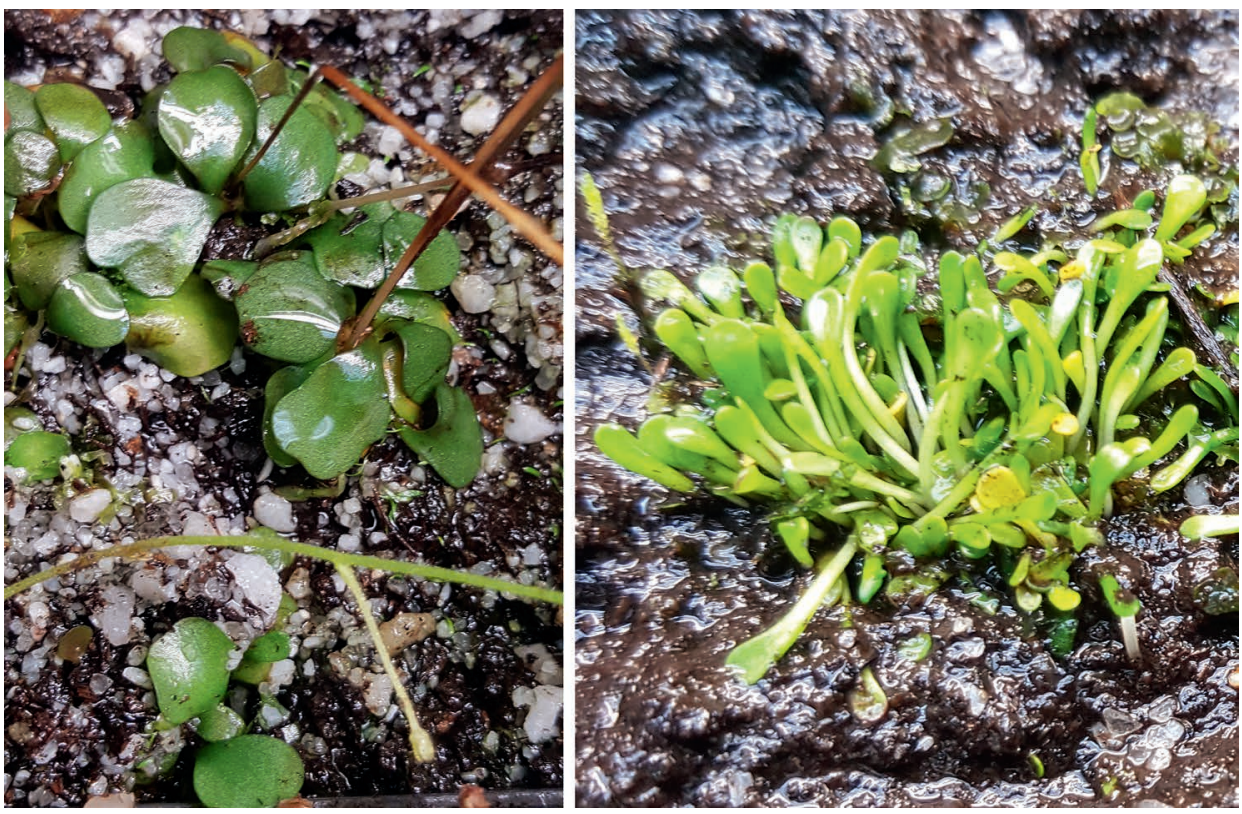

Figure 1: Spatulate leaves of Genlisea subglabra (left) and linear leaves of Genlisea roraimensis (right). 


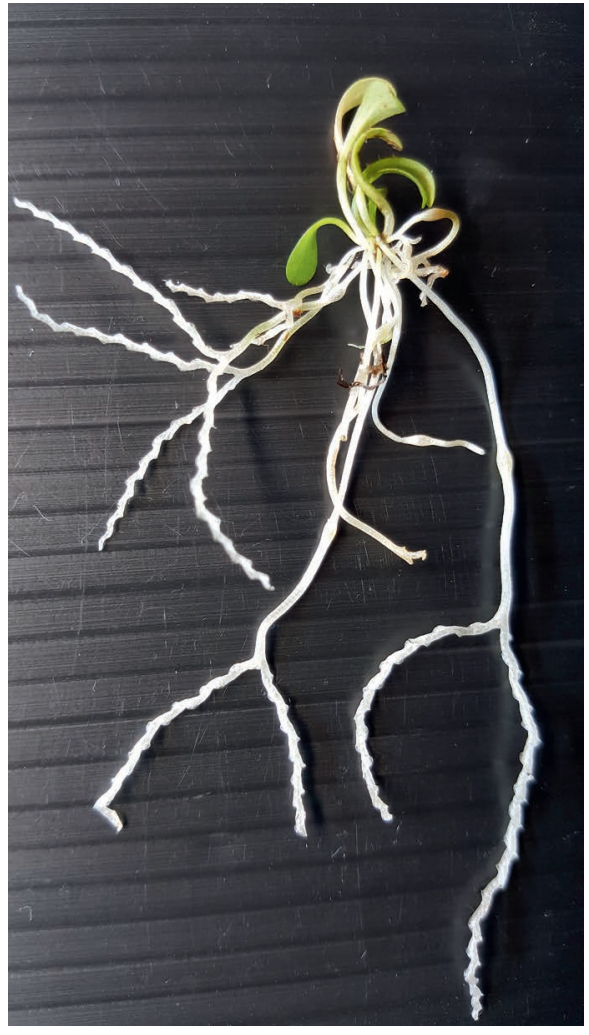

Figure 2: Genlisea traps. of this hollow tube, the leaf-trap divides into two twisted (flat) helical arms. The edges of this "ribbon" have dozens of holes through which prey can enter the trap. The inside of the trap is rich in small hairs turned inward, that is towards the vesicle, allowing the prey to only move toward the vesicle. Sometimes prey dies along the trap, before getting to the vesicle, and the plant assimilates the nutrients coming from the decomposition of those prey.

But why do prey enter the trap of Genlisea? At the moment there are no known mechanisms for attracting prey, and there are currently no known chemical attractants. The prey enters the traps perhaps without apparent reason or perhaps assuming a sort of dark "cave" that provides protection. The most common prey that have been found inside the traps are protozoa, small invertebrates, nematodes, and algae (Fleischmann 2012).

\section{Cultivation}

At the time of writing, I'm growing G. africana, G. aurea, G. exhibitionista, G. flexuosa, G. glandulosissima, G. hispidula, G. lobata, $G$. margaretae, G. nigrocaulis, G. oxycentron, $G$.

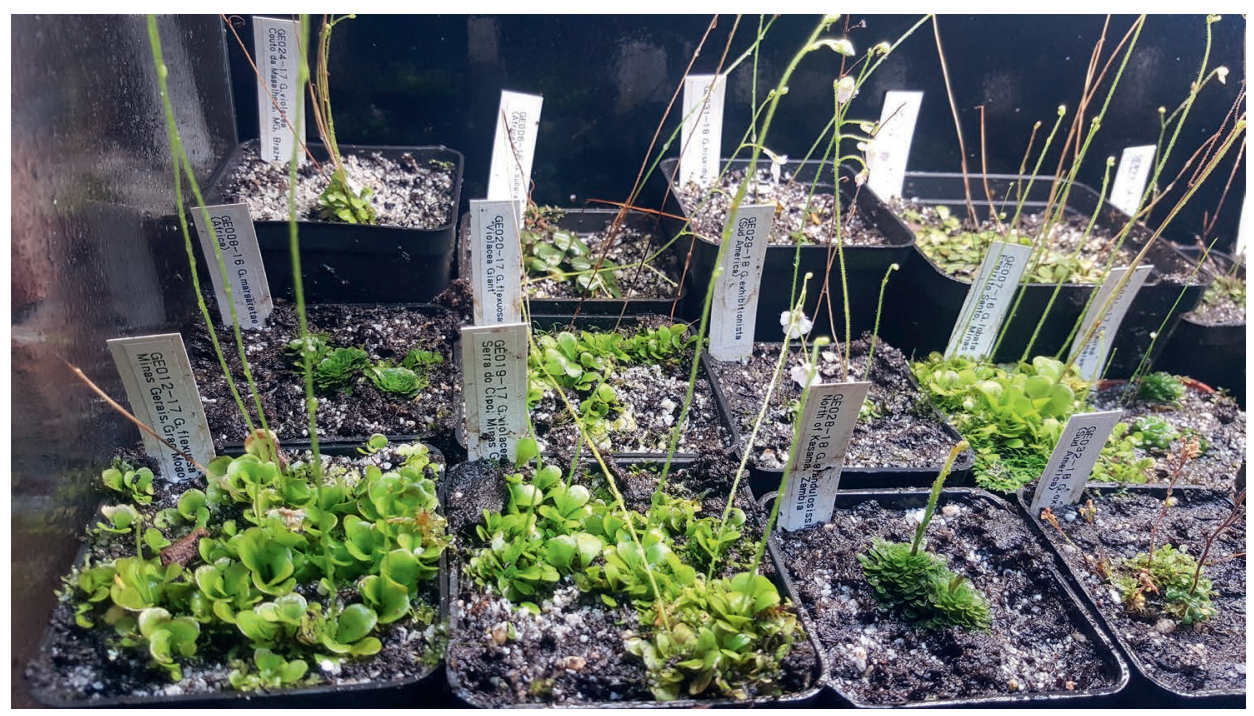

Figure 3: Genlisea growing in a terrarium. 
pygmaea, G. repens, G. roraimensis, G. subglabra, and G. violacea and my experience is about these species.

According to my experience, Genlisea cultivation is simple and, although the different species grow in places of the Earth that are distant from each other, I have managed to cultivate, reproduce, and make all these species bloom by cultivating them under the same conditions.

I keep my plants in terrariums (Fig. 3). The minimum temperature does not drop below 15$18^{\circ} \mathrm{C}$ at night, the water level is very high, it reaches the top edge of the pot. I add water from time to time, after letting the water level drop one or two centimeters.

My pots rest directly on the bottom of the terrariums where in the stagnant water, algae and deposits form. I rarely clean the terrarium; the micro fauna that forms on the bottom of the terrarium could feed my Genlisea.

The insolation in the places of origin, for the species I grow, is strong, so I keep the plants under T5 fluorescent tubes with different color gradation, the number of which depends on the size of the terrarium.

The pots must be at least $10-12 \mathrm{~cm}$ tall. Al-

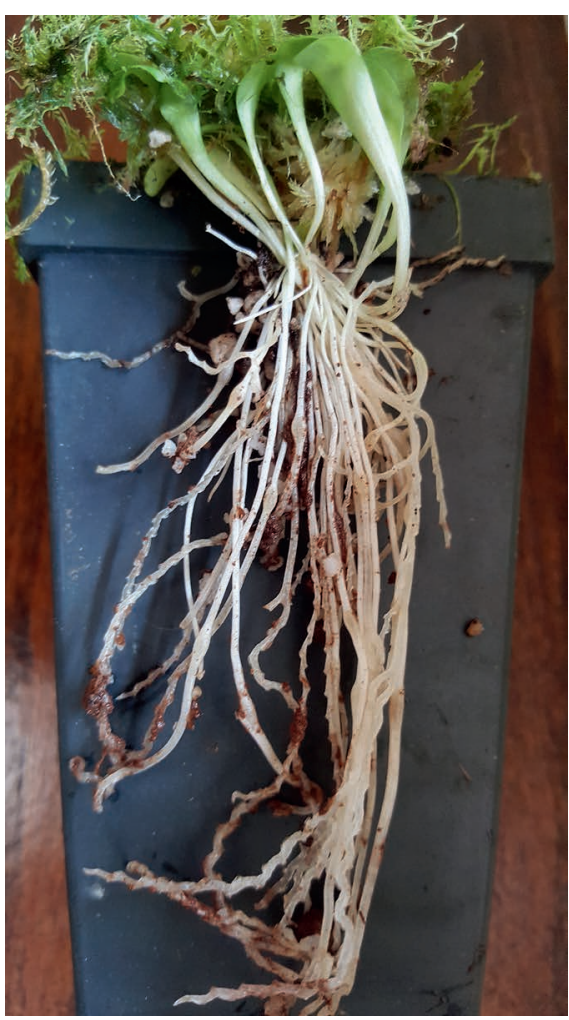

Figure 4: Genlisea growing in a deep pot. though the aerial part of the plant is small, the underground traps develop in unexpected lengths (Fig. 4). I tried different substrates without apparent changes in the development of different species, so today I use a mix composed of $70-80 \%$ quartz sand and the rest of peat.

Over the years, I have thought that live sphagnum could help maintain a healthy and moist environment. The idea is not wrong, but the sphagnum in the terrarium grows faster than any Genlisea species and I therefore abandoned the idea.

\section{Flowers and Pollination}

It is not easy to distinguish Genlisea plants from Utricularia plants if the traps cannot be observed, but the flowers of the two genera can easily help. The flowers of Utricularia have only two sepals, while Genlisea have five (Fig. 5).

Artificial pollination occurs exactly as for Utricularia or Pinguicula (remember that the three genera belong to the same botanical family). The small size of the flowers is certainly not an advantage! Equipped with an excellent view and a small tool to recover pollen (I use dry flower stems), the flower is held between the forefinger and thumb of my hand. The flower must be opened along its horizontal axis to expose inside of the flower. With a thin tool, the pollen is recovered from the stamens of the flower and dragged onto the pistils, which looks like a small lamella (opening) near the mouth of the flower. Small hands, a lot of delicacy, and a lens can be of great help! But with the 

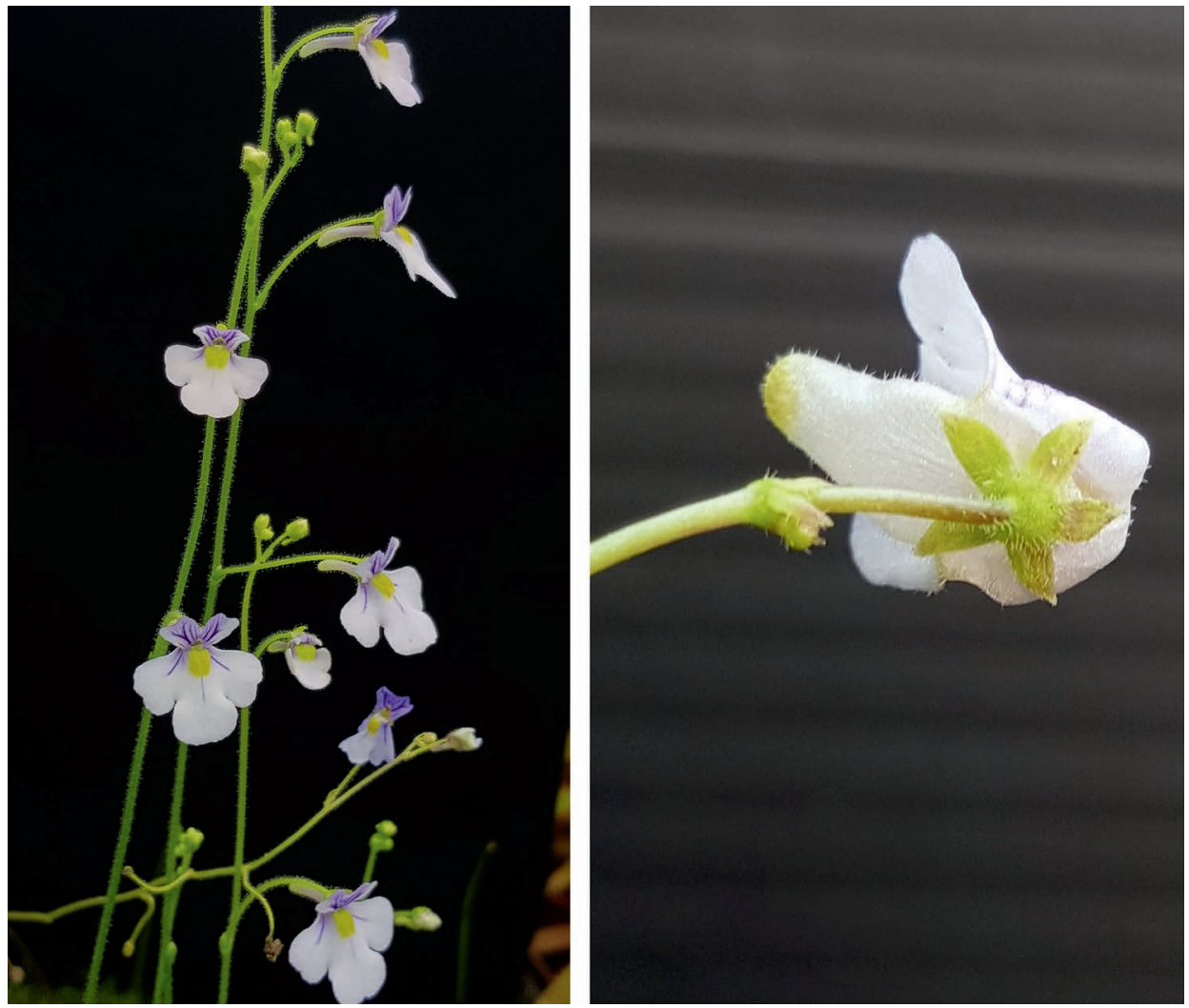

Figure 5: Flowers of the man-made hybrid Genlisea lobata x flexuosa (left). Genlisea flowers have 5 sepals (right).

flower in one hand and the small tool in the other, the magnifying glass must be held by a collaborator or you need a tripod.

\section{Multiplication}

For my experience G. africana, G. aurea, G. exhibitionista, G. flexuosa, G. hispidula, G. lobata, G. margaretae, G. pygmaea, G. roraimensis, G. subglabra, and G. violacea reproduces quite well by leaf or trap cuttings, I use the same substrate as the plants in cultivation. The leaf must be entirely resting on the surface of the media. In two or three weeks, the first traps emerge from the lower side of the leaf and enter the ground (Fig. 6). Later, several rosettes are formed which will give rise to more plants.

I use the same technique for the trap cutting, which turns out to be a good method because the traps are very delicate and break easily when handling plants.

Every now and then traps develop on the flower stem of my G. hispidula (Fig. 6). New plants will grow if the stem with plantlets is placed on the surface of the soil.

Reproduction by seed can be difficult. I have had rare successes and only with the seeds from my plants since the seeds must be very fresh in order to have the possibility of germinating. The 

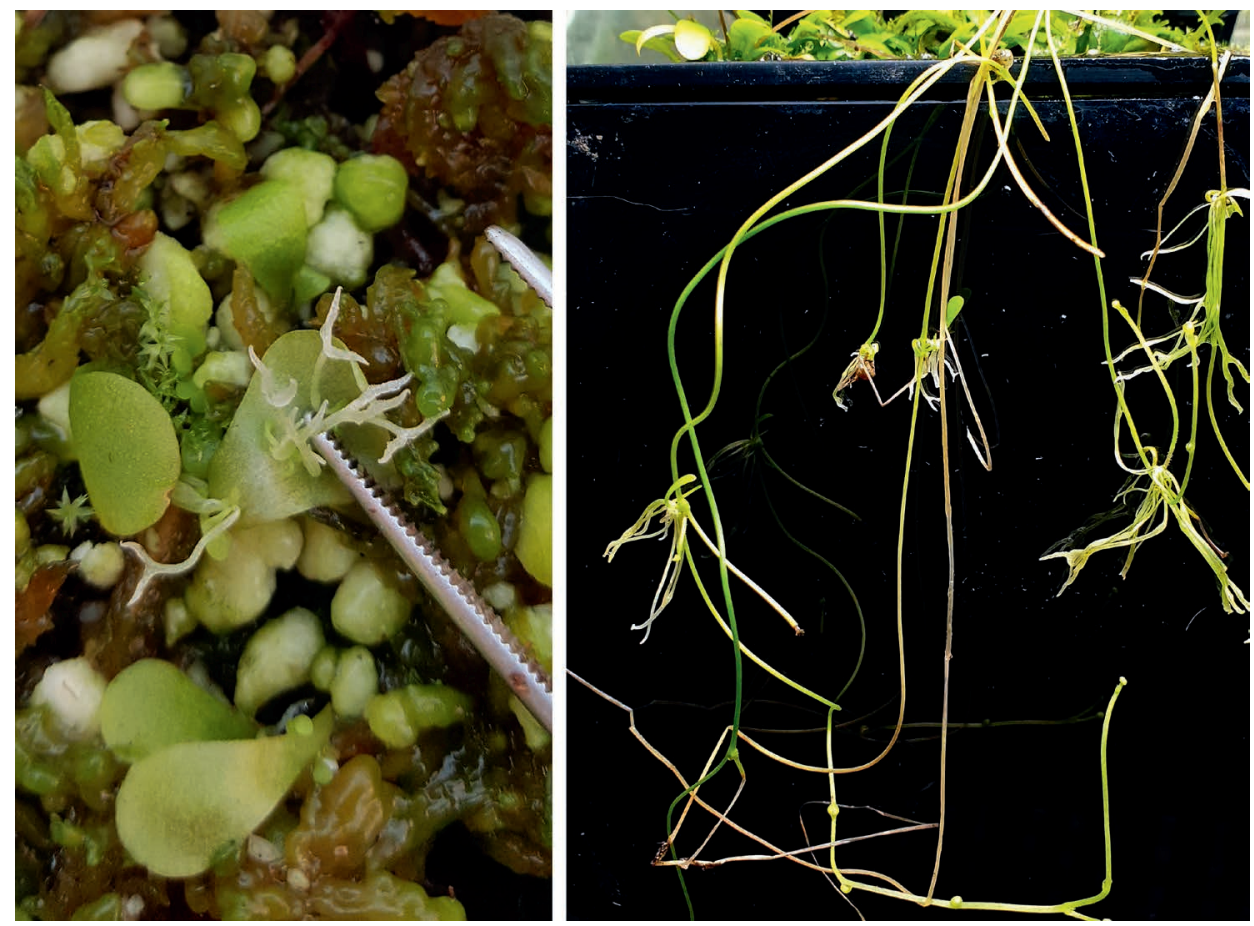

Figure 6: Rooted leaf cutting (left); plantlets forming on the flower stem (right).

small seeds are scattered on the surface of the pot without covering and the water level must exceed the height of the soil, taking care not to float the seeds, until the first shoots are seen, then the water level is lowered.

\section{Curiosity}

Genlisea aurea is completely covered with a mucilaginous substance. I spent a lot of time cleaning the plant believing that they were harmful algae, but Genlisea aurea continued to become covered with this substance until, years later, I read about this characteristic and I no longer pursue it!

\section{Reference}

Fleischmann, A. 2012. Monograph of the Genus Genlisea. Redfern Natural History Productions Ltd., Poole, UK. 


\section{CARNIVOROUS PLANT NEWSLETTER}

Journal of the International Carnivorous Plant Society

Volume 49, No. 1

March 2020

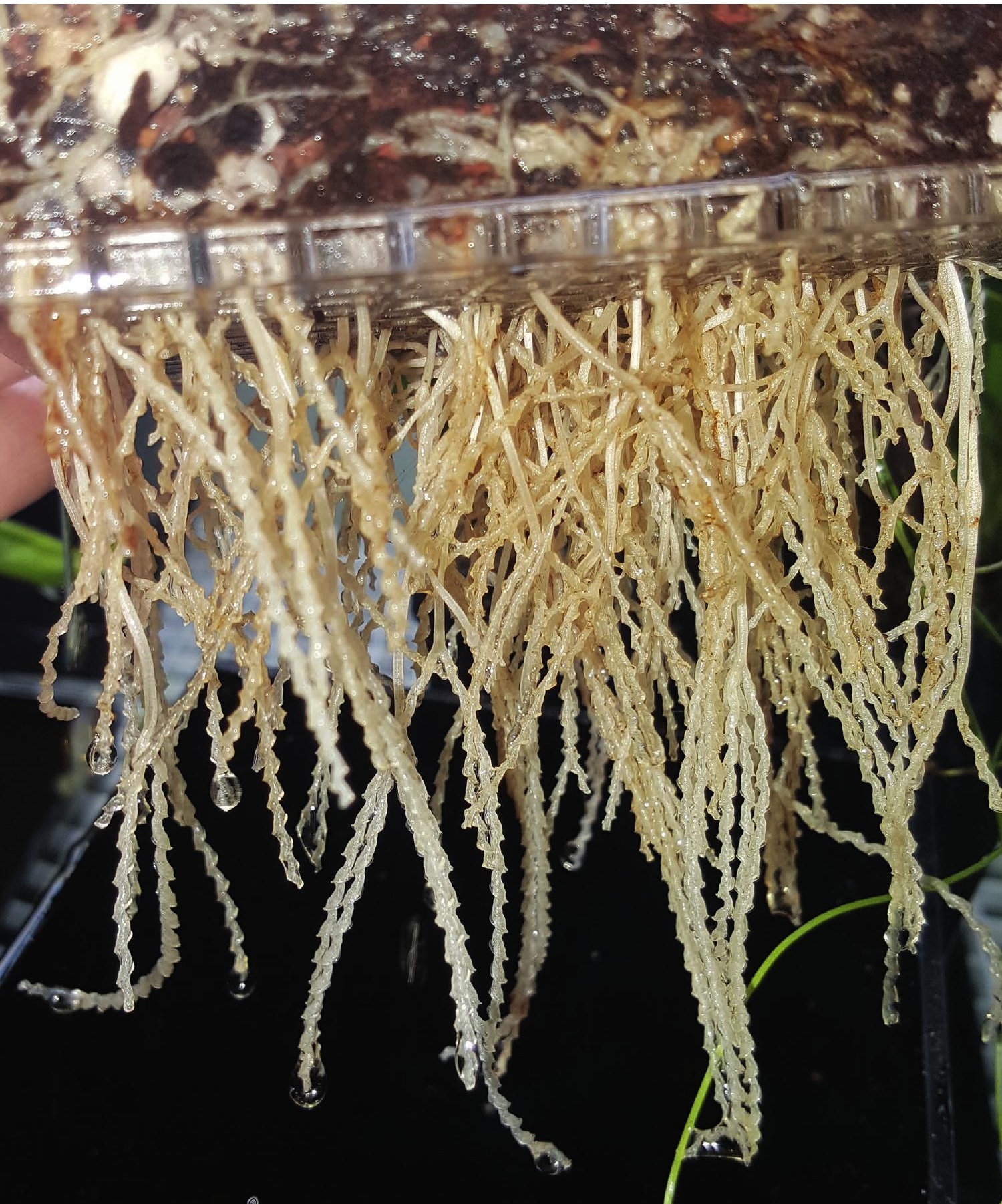




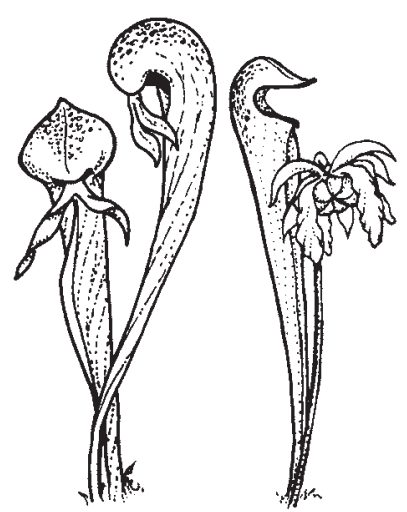

\section{CARNIVOROUS \\ PLANT \\ NEWSLETTER}

Journal of the International

Carnivorous Plant Society

www.carnivorousplants.org

\section{Volume 49, Number 1 March 2020}

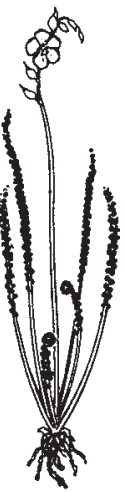

Front Cover: Traps of Genlisea hispidula growing through a plastic mesh. Photo by Rita Corino. Article on page 39.

Back Cover: Drosera coalara growing in yellow sand northeast of Badgingarra, Western Australia. Note the variability of style positions in the different flowers (left individual with upward-curved styles, middle with horizontal styles, right one somewhat in-between). Photo by Thilo Krueger. Article on page 6.

Carnivorous Plant Newsletter is dedicated to spreading knowledge and news related to carnivorous plants. Reader contributions are essential for this mission to be successful. Do not hesitate to contact the editors with information about your plants, conservation projects, field trips, or noteworthy events. Advertisers should contact the editors. Views expressed in this publication are those of the authors, not the editorial staff.

All correspondence regarding dues, address changes and missing issues should be sent to the Membership Coordinator at the ICPS. Do not send such correspondence to the editors. Checks for subscriptions should be made to the International Carnivorous Plant Society in US funds. Dues, including a subscription, are $\$ 30$ per year.

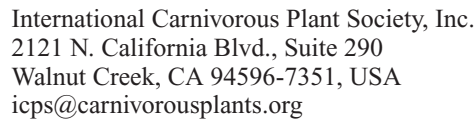

President

Vice President

Secretary

Treasurer

Board Member

Board Member

Board Member

Board Member

Membership Coordinator

Webmaster

Media Coordinator

Seed Bank Manager

CPN Editors

Managing Editor

Editor

Editor

Editor

Science Editor

Science Editor

Science Editor

\author{
Richard Nunn, richardnunn@carnivorousplants.org \\ John Brittnacher, john@carnivorousplants.org \\ Cindy Slezak, cindy@carnivorousplants.org \\ Daniela Ribbecke, daniela@carnivorousplants.org \\ Brent Jones, Conservation Director, brent@carnivorousplants.org \\ Kenny Coogan, Education Director, kenny@carnivorousplants.org \\ Jan Schlauer, Cultivar Registrar, jan@carnivorousplants.org \\ Bob Ziemer, bob@carnivorousplants.org \\ Cindy Slezak, cindy@carnivorousplants.org \\ John Brittnacher, john@carnivorousplants.org \\ Chad Williams, chad@carnivorousplants.org \\ Joe Griffin, joe@carnivorousplants.org \\ editor@carnivorousplants.org \\ Bob Ziemer \\ Barry Rice \\ Karl Herold \\ John Brittnacher \\ Andreas Fleischmann \\ Fernando Rivadavia \\ Jan Schlauer
}

Date of effective publication of the December 2019 issue of Carnivorous Plant Newsletter: November 8, 2019.

The ICPS is the International Cultivar Registration Authority (ICRA) for the names of cultivated carnivorous plants according to the International Code of Nomenclature for Cultivated Plants. Send relevant correspondence to the ICPS, Inc.

Carnivorous Plant Newsletter is published quarterly in March, June, September, and December by the ICPS, Inc., 2121 N. California Blvd., Suite 290, Walnut Creek, CA 94596, USA. Periodicals postage paid at Walnut Creek, CA and additional mailing offices. Postmaster: Send address changes to ICPS, Inc., 2121 N. California Blvd., Suite 290, Walnut Creek, CA 94596, USA. Printed by Allen Press, Inc., 810 E. 10th Street, Lawrence, KS 66044. Logo and masthead art: Paul Milauskas. (C) 2020 International Carnivorous Plant Society. All rights reserved. ISSN \#0190-9215 